Research Article

\title{
Analysis of Mechanical Properties of En19 Steel and En41b Steel Used In Diesel Engine Camshaft
}

\author{
N.V Diwakar $\dot{A}^{*}$, C. Bhagyanathan ${ }^{\dot{A}}$ and J. David Rathnaraj $\dot{\AA}$ \\ ${ }^{\AA}$ Manufacturing Engineering Department, Sri Ramakrishna Engineering College, Coimbatore \\ Accepted 10 January 2014, Available online 01 February 2014, Special Issue-2, (February 2014)
}

\begin{abstract}
Camshaft is one of the key parts or components in the engines of automobile and other vehicles. Due to the cyclic impact loading on the contacting surfaces of the cam and the follower, it often gives rise to premature wear of cam profile and affects a routine run of the valve gear such as the rotational speed, valve displacement and the torque. The objective of this work was to study experimentally the residual stresses at the surface layer of induction hardened cylindrical specimens. The diesel engine camshafts are generally made by EN19 Steel material. However, EN19 steel material has low wear resistance and its service life is shorter. ReplacingEN19 steel with EN41B steel. The results obtained from hardness test indicated that the hardness of the Nitride steel EN 41B is 31\% higher than EN19 Steel before induction hardening and the hardness of the Nitride steel EN41B is 45\% higher than EN19 steel after induction hardening. Impact test indicated that the toughness of Nitride steel EN41B is 38\% higher than EN19 steel.
\end{abstract}

Keywords: ANSYS, Induction Hardening, Pro/E model, Impact Test, Hardness Test.

\section{Introduction}

The camshaft is an apparatus often used in piston engines to operate poppet valves. It consists of a cylindrical rod running the length of the cylinder bank with a number of oblong lobes or cams protruding from it, one for each valve. The cams force the valves 7 open by pressing on the valve, or on some intermediate mechanism, as they rotate the relationship between the rotation of the camshaft and the rotation of the crankshaft is of critical importance. Since the valves control the flow of air/fuel mixture intake and exhaust gases, they must be opened and closed at the appropriate time during the stroke of the piston. For this reason, the camshaft is connected to the crankshaft either directly, via a gear mechanism, or indirectly via a belt or chain called a timing belt or timing chain. Duration can often be confusing because manufacturers may select any lift point to advertise a Camshaft's duration and sometimes will manipulate these numbers. The power and idle characteristics of a camshaft rated at .006 " will be much different than one rated the same at .002". Whenever duration is quoted, be sure to note the lift at which it is given. In general, duration determines how many crankshaft degrees a camshaft maintains more than a given tappet lifts. Depending on the location of the camshaft, the cams operate the valves either directly or through a linkage of pushrods and rockers. Direct operation involves a simpler mechanism and leads to fewer failures, but requires the camshaft to be positioned at the top of the cylinders. The rockers or cam followers sometimes

*Corresponding author: N.V Diwakar

DOI: http://dx.doi.org/10.14741/ijcet/spl.2.2014.29 incorporate a mechanism to adjust and set the valve play through manual adjustment, but most modern auto engines have hydraulic lifters, eliminating the need to adjust the valve lash at regular intervals as the valve train wears, and in particular the valves and valve seats in the combustion chamber.

\subsection{Classification of cams}

The cam, as a means of producing a given type of motion, is simple and reasonable to design, provided the simple principles are understood. Another advantage is that, generally, a cam can easily be changed or modified to allow a change of motion, without interfering with the remainder of the mechanism.

\subsection{Cam followers}

There are three types of cam followers, and since the type of follower influences the profile of the cam it is worthwhile considering the advantages and disadvantages of each type. The three types are the knife-edge, the roller follower and the flatfoot or mushroom follower.

\subsection{Diesel engine}

Highly fuel efficient, Greaves lightweight diesel engines are ideal for automotive applications like 2-wheelers, 3wheelers, mini cars etc. These engines with high power-toweight ratio are also used extensively for portable agricultural pump sets, gensets, small boats, construction 
equipment and host of other applications. Available in a range of 4-10 HP models, Greaves light diesel engines are widely used in Defense applications. These engines are manufactured at ISO 9001 certified Units in Aurangabad and Ranipet.

Table 1 Engine specifications

\begin{tabular}{|l|l|}
\hline Bore & $78 \mathrm{~mm}$ \\
\hline Stroke & $68 \mathrm{~mm}$ \\
\hline Displacement & $325 \mathrm{~cm}^{3}$ \\
\hline Compression ratio & $18: 01$ \\
\hline Rpm & $1500-1800$ \\
\hline Max. Torque & $2.96(29.03 \mathrm{~nm})$ \\
\hline S.F.C & $205220 \mathrm{gm} / \mathrm{h} . \mathrm{p} / \mathrm{hr}$ \\
\hline Lub oil consumption & $13 \mathrm{gm} / \mathrm{hr}$ \\
\hline Capacity of fuel tank & $4.5 \mathrm{liter}$ \\
\hline Capacity of oil sump & 1 liter \\
\hline Dry weight & $38 \mathrm{~kg}$ \\
\hline
\end{tabular}

\section{Problem identification}

\subsection{The diesel engine camshaft}

The diesel engine camshafts are generally made by EN19 Steel material. However, EN19 steel material has low wear resistance and its service life is shorter. In camshaft, particularly lobes suffer wear over time to a point where valve lift is reduced and engine performance is degraded. Also it necessitates frequent replacement leading to loss of time and money.

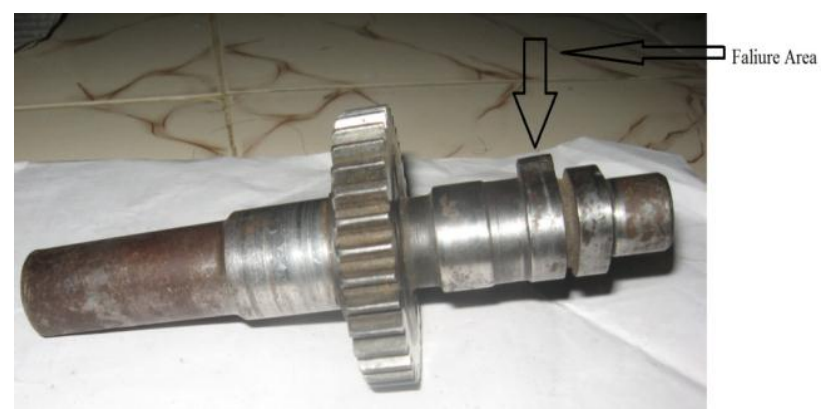

Figure 1 Failure of the Camshaft

Table 2 Chemical Composition of EN19 Steel

\begin{tabular}{|l|l|}
\hline Chemical & Composition \\
\hline $\mathrm{Fe}$ & $96.86 \%$ \\
\hline $\mathrm{C}$ & $0.38 \%$ \\
\hline $\mathrm{Si}$ & $0.21 \%$ \\
\hline $\mathrm{Mn}$ & $0.91 \%$ \\
\hline $\mathrm{P}$ & $0.01 \%$ \\
\hline $\mathrm{S}$ & $0.01 \%$ \\
\hline $\mathrm{Cr}$ & $1.04 \%$ \\
\hline $\mathrm{Mo}$ & $0.23 \%$ \\
\hline $\mathrm{Ni}$ & $0.23 \%$ \\
\hline $\mathrm{Al}$ & $4.21 \%$ \\
\hline
\end{tabular}

\subsection{Nitride Steel EN $41 B$}

To overcome above said, problem in camshaft an alternate material namely, Nitrite steel EN41B has been identified, chosen and analyzed for its performance.

Table 3 Chemical Composition of Nitride Steel EN 41B

\begin{tabular}{|l|l|}
\hline Chemical & Composite \\
\hline $\mathrm{AL}$ & $1.20 \%$ \\
\hline $\mathrm{C}$ & $0.40 \%$ \\
\hline $\mathrm{Cr}$ & $1.60 \%$ \\
\hline $\mathrm{Fe}$ & $95.55 \%$ \\
\hline $\mathrm{Mn}$ & $0.60 \%$ \\
\hline $\mathrm{Mo}$ & $0.35 \%$ \\
\hline $\mathrm{Si}$ & $0.30 \%$ \\
\hline
\end{tabular}

Application of Nitride Steel EN $41 B$

- Die casting dies

- Gears

- Plungers and cylinders

- Abrasive wheels

- Plastic mould parts

- Spindles

- Extrusion screws and barrels

\subsection{Case hardening}

The case hardening (or) surface hardening is the process of hardening the surface of metal, often low carbon steel, by infusing element into the material surface, forming a thin layer of a harder alloy.

\subsubsection{Case Hardening for Camshaft}

Depending on the application and economical reasons there are several materials for the manufacturing of cam and camshafts that require surface (or) case hardening. In this project, the two materials Nitride steel EN41B and EN19 Steel were hardened by induction hardening method for $1.5 \mathrm{~mm}$ case depth and the increment in the hardness were compared.

\subsubsection{Induction Hardening}

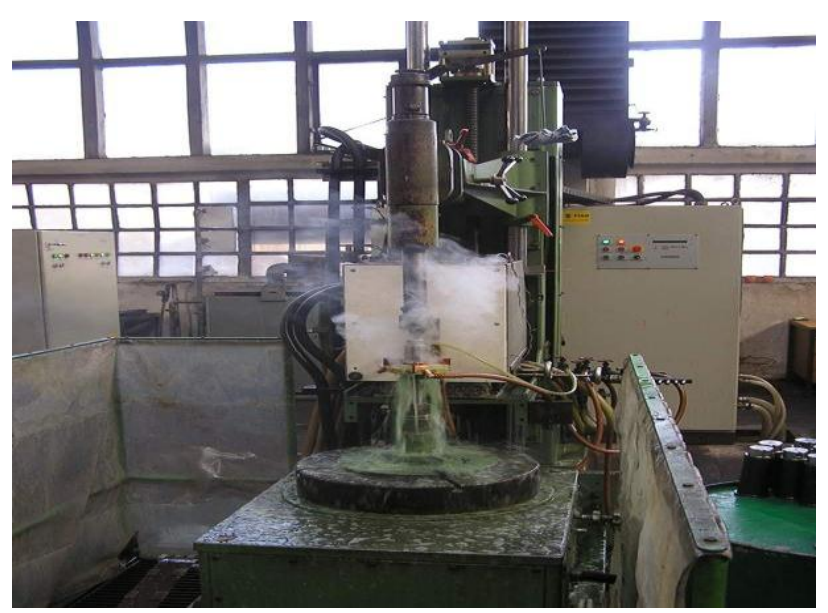

Figure 2 Induction Hardening

163 | International Conference on Advances in Mechanical Sciences 2014 
It is a form of heat treatment in which a metal part is heated by induction heating and then quenched, increasing the hardness and brittleness of the part. Induction hardening is used to selectively harden areas of a part or assembly without affecting the properties of the part as a whole.

\subsubsection{Principal methods}

- Single shot hardening

- Traverse hardening

\subsubsection{Purpose of Induction Hardening}

- It gives higher surface hardness of the steel

- The deformation produced is very small.

- The depth of heated surface can be easily controlled.

\section{Specimen preparation}

Table 4 Induction Hardening

\begin{tabular}{|l|l|}
\hline $\begin{array}{l}\text { TREATMENT } \\
\text { CONDUCTED }\end{array}$ & BEST HEAT TREATMENT,COIMBATORE \\
\hline Identification & EN19steel and Nitride Steel EN 41B \\
\hline Specimen & DIAMETER-10.5mm \\
\hline Case depth & $1.5 \mathrm{~mm}$ \\
\hline Power & $30 \mathrm{KW}$ \\
\hline Spindle speed & $2000 \mathrm{~mm} / \mathrm{min}$ \\
\hline
\end{tabular}

Table 5 Depth of Case Hardening

\begin{tabular}{|l|l|}
\hline MATERIAL & DEPTH OF CASE HARDENING \\
\hline EN19 steel & $1.5 \mathrm{~mm}$ \\
\hline $\begin{array}{l}\text { Nitride } \\
\text { EN41B steel }\end{array}$ & $1.5 \mathrm{~mm}$ \\
\hline
\end{tabular}

Table 6 Cylindrical Surface Grinding Cutting

\begin{tabular}{|l|l|l|}
\hline MATERIAL & $\begin{array}{l}\text { BEFORE SUFACE } \\
\text { GRINDING }\end{array}$ & $\begin{array}{l}\text { AFTER SURFACE } \\
\text { GRINDING }\end{array}$ \\
\hline EN19 steel & $10.5 \mathrm{~mm}$ & $10 \mathrm{~mm}$ \\
\hline $\begin{array}{l}\text { Nitride } \\
\text { EN41B steel }\end{array}$ & $10.5 \mathrm{~mm}$ & $10 \mathrm{~mm}$ \\
\hline
\end{tabular}

\subsection{Specimen preparation for Toughness test}

Table 7 Material Sizes

\begin{tabular}{|l|l|l|}
\hline MATERIAL & DIAMETER & LENGTH \\
\hline EN19 steel & $16 \mathrm{~mm}$ & $300 \mathrm{~mm}$ \\
\hline $\begin{array}{l}\text { Nitride } \\
\text { EN41B steel }\end{array}$ & $20 \mathrm{~mm}$ & $300 \mathrm{~mm}$ \\
\hline
\end{tabular}

Table8Milling, Cutting and Notching

\begin{tabular}{|l|l|l|}
\hline OPERATION & EN19 STEEL & $\begin{array}{l}\text { NITRITE En 41B } \\
\text { STEEL }\end{array}$ \\
\hline Milling & $6 \mathrm{~mm}$ & $10 \mathrm{~mm}$ \\
\hline Cutting & $55 \mathrm{~mm}$ & $55 \mathrm{~mm}$ \\
\hline Notching & $2 \mathrm{~mm}$ & $2 \mathrm{~mm}$ \\
\hline
\end{tabular}

Table 9 Specimens for Toughness Test

\begin{tabular}{|l|l|l|l|}
\hline MATERIAL & LENGHT & WIDTH & BREATH \\
\hline EN19 steel & $55 \mathrm{~mm}$ & $10 \mathrm{~mm}$ & $10 \mathrm{~mm}$ \\
\hline $\begin{array}{l}\text { Nitride } \\
\text { EN41B steel }\end{array}$ & $55 \mathrm{~mm}$ & $10 \mathrm{~mm}$ & $10 \mathrm{~mm}$ \\
\hline
\end{tabular}

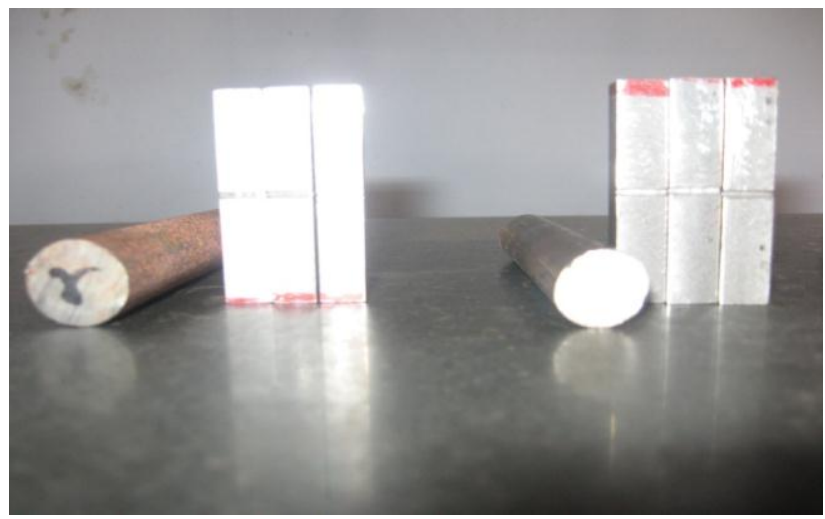

Figure 3 Specimens for impact test

\section{Testing of Nitride Steel En41b Specimens \\ 4.1Mechanical test}

Mechanical test is an essential part of any engineering activity. Mechanical test is applied to the materials, components and assemblies.It consists of measurement of fundamental properties or measurement of responses to particular influences such as load, temperature, etc

Types of mechanical tests carried out in Nitride steel EN41B Materials are,

- Hardness test

- Impact test

These tests are conducted to analyze the hardness, toughness and wear resistance properties of Nitride steel EN41B Material. These tests are carried out in different types of testing machines. They are

- Rockwell Hardness Testing Machine

- Charpy Testing Machine

\subsubsection{Impact test}

In this project, the impact test was carried out by CHARPY TEST to find the impact energy.

\section{Charpy Test}

The Charpy test uses a test specimen of size $10 \mathrm{~mm} x$ $10 \mathrm{~mm} \times 55 \mathrm{~mm}$ (sub size specimen). The impact specimen received without notch and the depth of the notch is $2 \mathrm{~mm}$.

Testing Procedure

The general procedure to conduct an impact test is given below:

a. The specimen is placed in the vice of the anvil

b. The pendulum hammer is raised to known standard height depending on the type of specimen to be tested 
c. When the pendulum is released, its potential energy is converted into kinetic energy just before it strikes the specimen.

d. Now the pendulum strikes the specimen. It may be noted that the Izod specimen is hit above the V-notch and Charpy specimen will be hit behind the V-notch.

e. The pendulum, after rupturing the specimen, rises on the other side of the machine.

f. The energy absorbed by the specimen during breaking is the weight of the pendulum times the difference in two height of the pendulum on the either side of the machine.

g. Now the energy i.e., the notch impact strength, in foot-pounds or meter-kg, is measured from the scale of the impact testing machine.

\section{Result and Discussion}

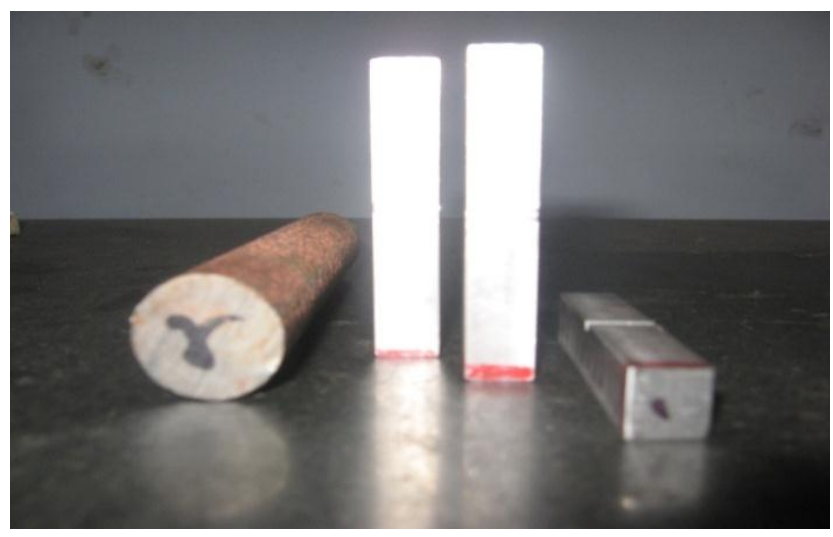

Figure 4 Nitride steel EN41B for Impact test

Impact Test for Nitrite Steel EN41B

Identification Nitride steel EN41B

Type of test Charpy V-notch $2 \mathrm{~mm}$ depth

Specimen size $10 \mathrm{~mm} \times 10 \mathrm{~mm}$ x $55 \mathrm{~mm}$

Table 10 Impact Test for Nitride Steel EN 41B

\begin{tabular}{|l|l|}
\hline IDENTIFICATION & IMPACT ENERGY IN (J) \\
\hline \multirow{3}{*}{ Nitride Steel EN 41B } & 40 \\
\cline { 2 - 2 } & 39 \\
\cline { 2 - 2 } & 40 \\
\hline
\end{tabular}

Impact Test for EN19 Steel

$\begin{array}{ll}\text { Identification } & \text { EN 19 steel } \\ \text { Type of test } & \text { Charpy V-notch 2mm depth } \\ \text { Specimen size } & 10 \mathrm{~mm} \text { x 10mm x 55mm }\end{array}$

Table 11 Impact Test for Nitride Steel EN 41B

\begin{tabular}{|l|l|}
\hline IDENTIFICATION & IMPACT ENERGY IN (J) \\
\hline \multirow{3}{*}{ EN19 steel } & 28 \\
\cline { 2 - 2 } & 30 \\
\cline { 2 - 2 } & 29 \\
\hline
\end{tabular}

4.1.2 Rockwell Hardness Test
The hardness test is performed when quick and reading is required and also when the materials have hardness beyond the range of brinell hardness test. It differs from the brinell hardness tests that in this test loads for the making indentions are smaller and thus make small and shallow indentations. Due to these reason, the Rockwell hardness test is widely used in the industry.

The Advantages of the Rockwell hardness Test is given below

1) The testing is relatively fast

2) The hardness is directly read on the scale

3) There is no impairment for the testing material since a small indentation is left on the objects.

4) Use of the initial minor load avoids the errors arising out of the uneven surface of the material and other instrumental errors.

\section{Hardness Test for Nitride Steel EN41B}

Test Conducted at Best Heat Treatment Coimbatore

Equipment used Rockwell Hardness Tester

Identification Nitride steel EN41B

Table 12 Before Hardness Test for Nitride Steel EN41B

\begin{tabular}{|l|l|}
\hline SERIAL NUMBER & HARDNESS \\
\hline 1 & $17 \mathrm{HRC}$ \\
\hline 2 & $16 \mathrm{HRC}$ \\
\hline 3 & $17 \mathrm{HRC}$ \\
\hline
\end{tabular}

Table 13After Hardness Test for Nitride Steel EN41B

\begin{tabular}{|l|l|}
\hline SERIAL NUMBER & HARDNESS \\
\hline 1 & $58 \mathrm{HRC}$ \\
\hline 2 & $58 \mathrm{HRC}$ \\
\hline 3 & $58 \mathrm{HRC}$ \\
\hline
\end{tabular}

\section{Hardness Test for EN 19 Steel}

Test Conducted at Best Heat Treatment Coimbatore Equipment used Rockwell Hardness Tester Identification EN19 STEEL

Table 14 Before Hardness Test for EN19 Steel

\begin{tabular}{|l|l|}
\hline SERIAL NUMBER & HARDNESS \\
\hline 1 & $13 \mathrm{HRC}$ \\
\hline 2 & $13 \mathrm{HRC}$ \\
\hline 3 & $13 \mathrm{HRC}$ \\
\hline
\end{tabular}

Table 15 After Hardness Test for EN19 Steel

\begin{tabular}{|l|l|}
\hline SERIAL NUMBER & HARDNESS \\
\hline 1 & $40 \mathrm{HRC}$ \\
\hline 2 & $40 \mathrm{HRC}$ \\
\hline 3 & $40 \mathrm{HRC}$ \\
\hline
\end{tabular}




\section{Modeling and Analysis of camshaft using Pro-E}

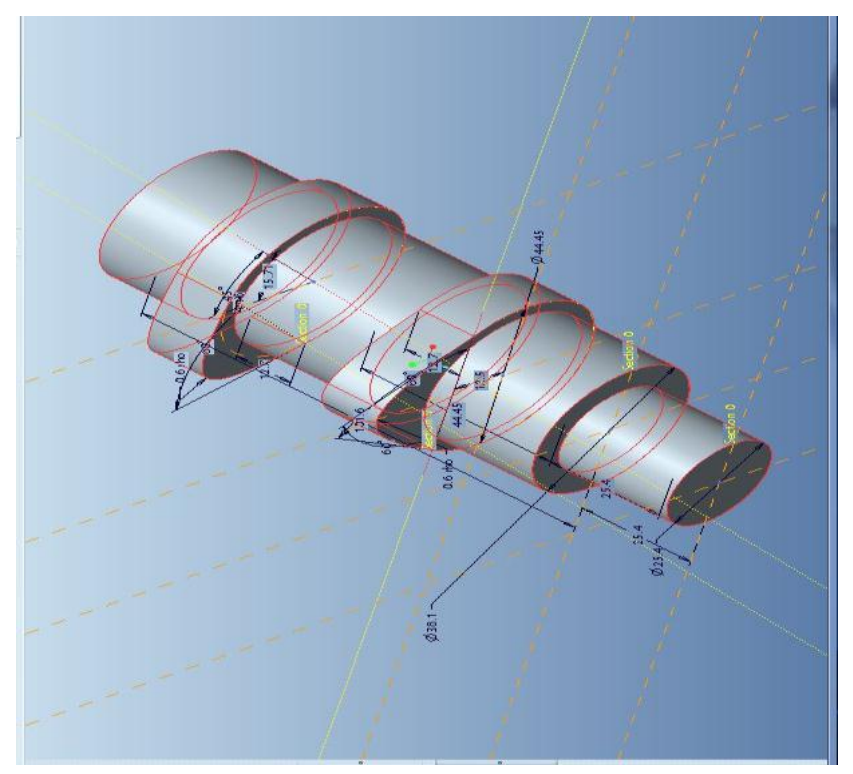

Figure 5 Modeling of camshaft

\section{Result}

Table 16 Hardness Test Result before Induction Hardening

\begin{tabular}{|l|l|l|}
\hline MATERIAL & HARDNESS \\
\hline & $\begin{array}{l}\text { BEFORE } \\
\text { INDUCTION } \\
\text { HARDENING }\end{array}$ & $\begin{array}{l}\text { AFTER } \\
\text { INDUCTION } \\
\text { HARDENING }\end{array}$ \\
\hline EN19 steel & 13HRC & 40HRC \\
\hline $\begin{array}{l}\text { Nitride Steel } \\
\text { EN 41B }\end{array}$ & $17 \mathrm{HRC}$ & $58 \mathrm{HRC}$ \\
\hline
\end{tabular}

The percentage of hardness $=\frac{17-13}{13} \times 100$

$=31 \%$

Therefore, the Nitride steel EN41B has $31 \%$ higher hardness than EN19 Steel.

After induction hardening

The percentage of hardness $\quad=\frac{58-40}{40} \times 100$

$=45 \%$

Therefore, the Nitride steel EN41B has $45 \%$ higher hardness than EN19 Steel.

\section{Toughness test}

Table 17 Toughness Test Result

\begin{tabular}{|l|l|}
\hline MATERIAL & IMPACT ENERGY IN (J) \\
\hline EN19 steel & 29 \\
\hline $\begin{array}{l}\text { Nitride Steel } \\
\text { EN 41B }\end{array}$ & 40 \\
\hline
\end{tabular}

The percentage of toughness $=\frac{40-29}{29} \times 100$ $=38 \%$

Therefore, the Nitride steel has $38 \%$ higher toughness than EN19 steel. ANSYS

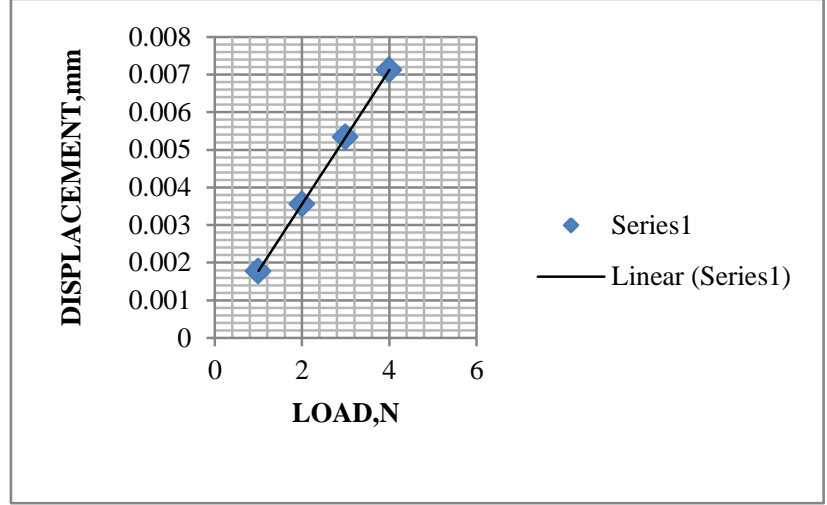

Figure 6 Displacements vs. Load for EN19 steel

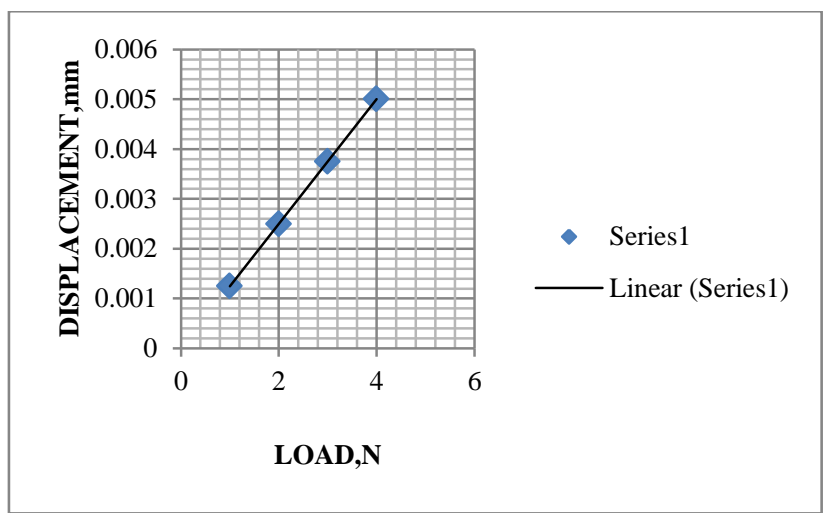

Figure 7 Displacement vs. Load for nitride steel en $41 b$ steel

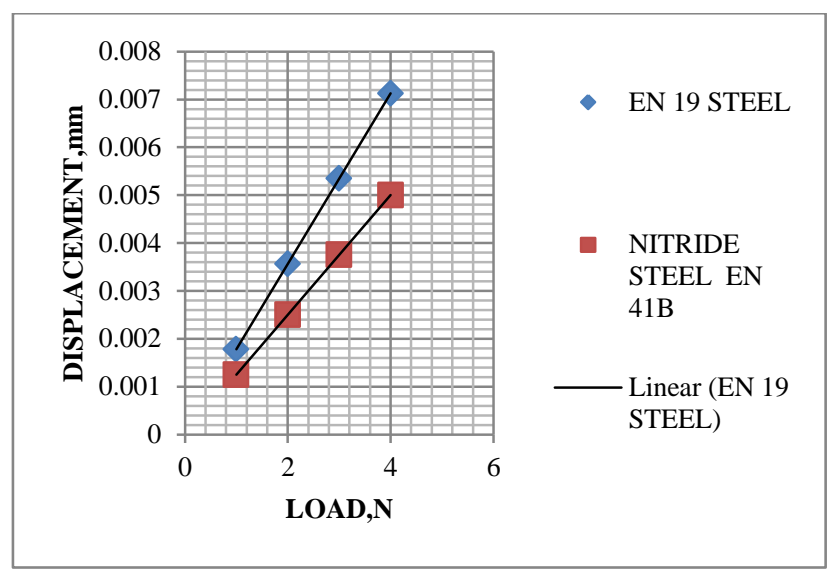

Figure 8 Comparisons of EN19 steel and nitride steel en41b

\section{Conclusion}

In this project the suitable alternate material Nitride steel EN41B has been identified and analyzed for the diesel engine camshaft instead of EN19 Steel material. Since the existing material necessitates frequent replacement leading to loss of time and money. Mechanical properties such as hardness, toughness and wear resistance of Nitride steel EN 41B were studied. In addition stress analysis was carried out using ANSYS. 
The results obtained from hardness test indicated that the hardness of the Nitride steel EN 41B is $31 \%$ higher than EN19 Steel before induction hardening and the hardness of the Nitride steel EN41B is $45 \%$ higher than EN19 steel after induction hardening with $1.5 \mathrm{~mm}$ case depth. Impact test indicated that the toughness of Nitride steel EN41B is $38 \%$ higher than EN19 steel. In addition, ANSYS results showed that Nitride steel EN41B camshaft suffered lower displacement than EN19 steel camshaft for all load conditions. From these results it can be observed that camshaft made using Nitride steel EN41B has higher service life.

\section{References}

A.S.Dhavale, V.R.Muttagi, (2012) Study of Modeling and Fracture Analysis of Camshaft, International Journal of Engineering Research and Applications, Vol. 2, Issue 6.

A.Gopichand, Dr.M.Muralidhara rao, Prof A.V.N.L.Sharma V.Samuel tony,(2012) Analysis and Estimation of Attenuation Coefficient of Aging EN-19 Steel, International Journal of Engineering Research and Applications (IJERA) ISSN: 22489622 ,

Ivo Dolezela, Jerzy Barglikb, Bohus Ulrychc,(2005)"Continual induction hardening of axi-symmetric bodies", Journal of Materials Processing Technology 161 269-275.

R. V. Wanjari, T. C. Parshiwanikar, (2013)"Design and Analysis of Camshaft by Changing Parameters which Causes Failure", International Journal of Science and Modern Engineering (IJISME) ISSN: 2319-6386, Volume-1, Issue-6,

H. Kristoffersen, P. Vomacka,(2001) "Influence of process parameters for induction hardening on residual stresses", Materials and Design.637_644.
Y. Totik1, R. Sadeler, H. Altun, M. Gavgali,(2002) "The effects of induction hardening on wear properties of AISI 4140 steel in dry sliding conditions", Materials and Design.

Khamlichi,A.,Bezzazi,M.,Jabbouri,A.,ReisP.andDavim,J.P(2008) ,"Optimizing friction behavior of clutch facing using pin ondisk test", International journal of physical sciences Vol.3(2).

Wafaa M.Salih,Sanaa M.Salih and Myada M.Salih and Myada M.Salih(2008),"The effect of time variation on the wear sliding Behavior of composite", Journal of Engineering and Applied Sciences.

R.Singha Roy, Dr.A.Chanda, D Basu,(2005),"A Comparative study of Alumina Wear in Air and Distilled Water"

R.Choteborsky,P.Hrabe,M.Muller,J.Savkova,M.Jirka(2005),"Abr asive wear of high Chromium $\mathrm{Fe}-\mathrm{Cr}-\mathrm{C}$ hard facing alloys".

M.Ignatiev,I.Smurov,V.Martino,G.Flamant and C.Duty(1994),"Application of Laser surface alloying for improvement of wear resistance of bearing steel working at severe conditions and of light titanium alloys", Journal De Physique IV.

A.Wiengmoon,T.Chairuangsri,N.Chomsang,N.Poolthong,J.T.H. Pece,"Effect of Heat Treatment on Hardness and Dry Properties of A Semi-Solid Processed Fe-27wt\%Cr-2.9wt\%c Cast Iron".

Th.Gradt, H.Borner, W.Hubner, Low Temperature Tribology at the Federal Institute For Material Research And Testing, Federal Institutes for Materials Research and Testing.

M.Arumugam, 2002,"materialscience", anuradh agencies, kumbakonam.

P.C.Sharma, 2004,"production technology", S.Chanda and company ltd, ram nagar, new delhi-110 055 . 